\title{
TEXTILBETON SZERKEZETI ELEMEK
}

\section{TEXTILE-REINFORCED CONCRETE STRUCTURAL ELEMENTS}

\author{
Libotean Dan Alexandru ${ }^{1}$, Chira Alexandru ${ }^{2}$, Gobesz Ferdinánd-Zsongor ${ }^{3}$ \\ ${ }^{1}$ Kolozsvári Müszaki Egyetem, Épitömérnöki Kar, Tartószerkezetmechanikai Tan- \\ szék, 400020, Románia, Kolozsvár, C. Daicoviciu u. 15, II. em., 204, Tel. +40-264- \\ 401313, liboteandanalexandru@yahoo.com \\ ${ }^{2}$ Kolozsvári Müszaki Egyetem, Épitömérnöki Kar, Tartószerkezetmechanikai Tan- \\ szék, 400020, Románia, Kolozsvár, C. Daicoviciu u. 15, II. em., 204, Tel. +40-264- \\ 401313,alexandru.chira@mecon.utcluj.ro \\ ${ }^{3}$ Kolozsvári Müszaki Egyetem, Építömérnöki Kar, Tartószerkezetmechanikai Tan- \\ szék, 400020, Románia, Kolozsvár, C. Daicoviciu u. 15, III. em., 305, Tel. +40-264- \\ 401351,go@mecon.utcluj.ro
}

\begin{abstract}
The textile reinforced concrete is a material with increased mechanical properties that can allow the production of lighter structural elements. The alkali-resistant textile reinforcement is not affected by corrosion. A structural facade panel and a light pole were modelled in order to study their behavior in case of wind pressure. The developed numerical simulations were calibrated upon the available data from the literature. These simulations revealed some information that may worth to be taken into consideration in order to plan further experimental tests.
\end{abstract}

Keywords: textile reinforced concrete, alkali-resistant glass-fibers, finite element method, numerical simulations.

\section{Összefoglalás}

A textilbeton olyan lúgálló hálóval megerősített beton, amely ellenáll a korróziónak. Mechanikai tulajdonságainak köszönhetően könnyebb szerkezeti elemek megvalósítására is alkalmazható. Egy homlokzati lemez meg egy lámpaoszlop szélnyomás alatti viselkedése lett modellezve és tanulmányozva. A szakirodalombeli adatok alapján kalibrált numerikus szimulációk olyan információkat nyújtottak, melyeket a további gyakorlati kísérletek tervezésekor lehet, hogy érdemes figyelembe venni.

Kulcsszavak: textilbeton, lúgálló üvegszálak, végeselem módszer, numerikus szimulációk.

\section{Bevezetés}

A nagyszilárdságú (HPC) és ultra nagy szilárdságú (UHPC) betonok megjelenésével párhuzamosan felmerült a vasbeton szerkezetek fenntartható fejlődését elősegítő technológiák kifejlesztésének a szüksé- gessége és alkalmazása. Az utóbbi években az építészek és a szerkezettervezők részéről egyre nagyobb érdeklődés nyilvánult meg az innovatív és a nagyszilárdságú anyagok alkalmazása iránt, s ez az építőanyagok meg a kompozit elemek folyamatos fejlődéséhez vezetett. A tüzvédelmi elöírások és a 
korrózióvédelem miatt a hagyományos acél vasalások kivitelezéséhez minimálisan $5 \mathrm{~cm}$ vastagság szükséges bármely szerkezeti vasbeton elemnél. A nagyszilárdságú betonok szálerősítésekkel és hálókkal (lúgálló polimer bevonatú üveg-, bazalt-, szénszálakból) kombinálva akár tízszeresen vékonyabb elemek gyártását is lehetővé tehetik, nagyobb mechanikai szilárdsággal a hagyományos rendszerekhez képest. A fenntarthatósági követelmények szempontjából a textilbeton (TRC) alkalmazása előnyös lehet, a csekélyebb anyagszükséglet és a kisebb ökológiai lábnyom miatt. Számos tanulmányt végeztek e téren a szerkezeti megfelelőség, időtállóság, gyártás, alkalmazási lehetőségek vagy formatervezés szempontjából.

A TRC elemek elöállításához általában finomszemcsés betont használnak, olyan adalékanyaggal melynek a szemnagysága nem haladja meg a 2 mm-t. Ez az apró szemnagyság nemcsak a beton szilárdságát növeli (egyébként is HPC és UHPC betonféléket alkalmaznak), hanem a szövetszálak jobb rögzítését is biztosítja a cement mátrixban [1]. A TRC elemek megerösítéséhez általában olyan sík vagy térbeli hálókat alkalmaznak, melyeknek a rostjait lúgálló üveg- (ARG), szén-, bazalt-, polipropilén szálak, polivinil-klorid (PVC) bevonatú polivinil-alkohol (PVAc), vagy ezek hibrid változatai alkotják [2].

A TRC egy olyan kompozit anyag, mely nagyon széles körben alkalmazható, akár szerkezeti rehabilitációknál [3-7], könnyü teherhordó szerkezetekhez [8, 9], vagy homlokzati lemezekhez [10-14]. A TRC elemek geometriájától függően többféle formázási módszert alkalmaznak: zsaluzást, szórást vagy laminálást [15].

A jelen tanulmány célja olyan információk gyüjtése volt, amelyek néhány széltehernek kitett TRC szerkezeti elem (esetünkben teherbíró homlokzati lapok és lámpa-oszlopok) viselkedésére vonatkoznak. E célból néhány numerikus szimulációt vé- geztünk el ezekre az elemfajtákra, az Abaqus [16] végeselem programcsomag használatával. Ezek a vizsgálatok ugyanakkor egy kezdeti, a későbbi gyakorlati kísérleteket megelőző fázist is képviselnek.

\section{Anyagok és eljárások}

\subsection{Anyagmodellek}

A textilerősítésekhez olyan sík üvegszálas háló alkalmazását modelleztük, amilyen az 1. ábrán látható. A hálót képzö rostok egyenként körülbelül 1500-2000 szálból vannak fonva és epoxigyanta alapú polimer bevonattal vannak borítva. A csomópontok láncszemként vannak kialakítva és a hálószemek méretei $10 \times 25 \mathrm{~mm}$. A rostok keresztmetszeti felülete $3,80 \mathrm{~mm}^{2}$ és a számításokhoz $33250 \mathrm{MPa}$ értékủ rugalmassági modulust, illetve $475 \mathrm{MPa}$ értékü szakítószilárdságot vettünk figyelembe.

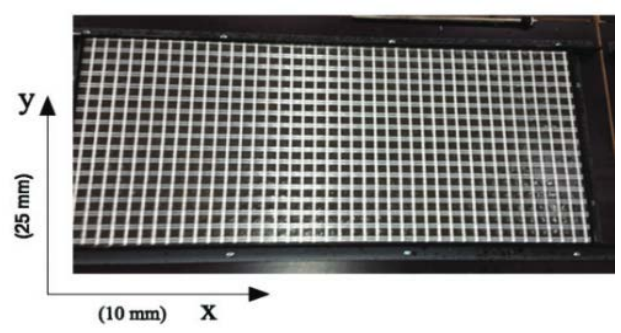

1. ábra. „2D AR-Glass” textilerősités [11].

Többféle típusú beton volt a numerikus modellezés során figyelembe véve, így, a hagyományosnak számító közönséges C25/30 és C20/25 osztályú betonok mellett az alábbi textilbetonok jellemzőivel készültek a modellek:

- TRC106 / C106 (nyomószilárdság: 106 MPa, E = $49 \mathrm{GPa}$ );

- TRC90 (nyomószilárdság 90 MPa, E = 40 GPa);

- TRC70 (nyomószilárdság 70 MPa, E = 35 GPa). 


\subsection{A szerkezeti elemek}

A 25x300x700 mm-es homlokzati lemezek a 2. ábrán látható feltámasztással és terhelési móddal lettek modellezve (az öt említett betontípussal, külön-külön, 6 mmes betonfedéssel). Ez a terhelési mód megegyezik a majdani gyakorlati kísérletekben alkalmazandóval.

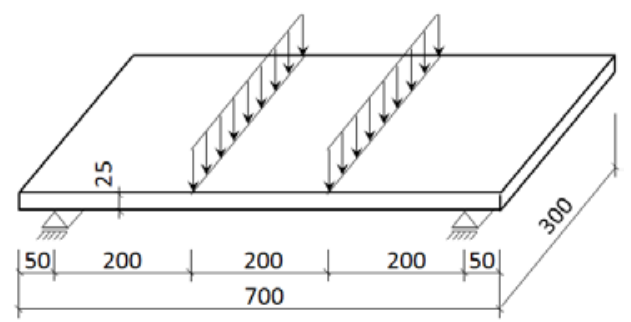

2. ábra. Homlokzati lemezmodell, fektetve (a méretek mm-ben vannak feltüntetve).

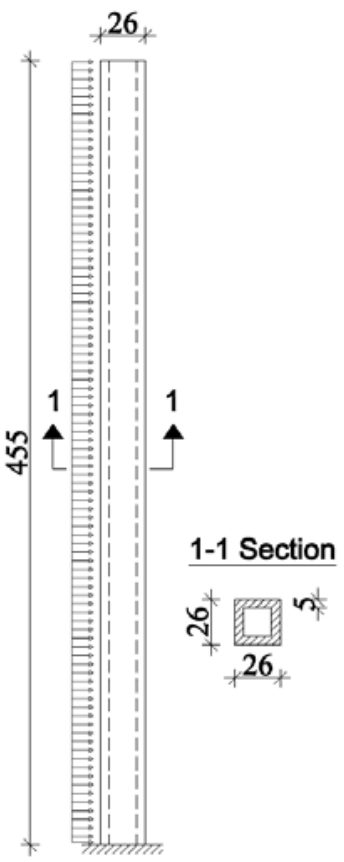

3. ábra. Lámpaoszlop modell (a méretek $\mathrm{cm}$ ben vannak feltüntetve).

A 260x260x4550 mm-es TRC lámpaoszlop 10x10 mm-es hálószem méretű meg- erősítéssel lett modellezve (ugyanazokat a mechanikai jellemzőket alkalmazva, mint a már említett „2D AR-Glass” hálónál). A hosszanti erösítések a keresztmetszeti fal közepébe voltak elhelyezve. A homlokzati lemezektől eltérően, itt csak három eset volt tanulmányozva: C106-os textilbeton, C106os beton (erösítés nélkül), illetve C20/25-ös osztályú közönséges beton szintén erősítés nélkül. E modellek rögzítési és terhelési módja a 3. ábrán látható.

\subsection{Számszerú vizsgálati módszer}

Az erősítések modellezéséhez rúd alakú, két csomóponttal rendelkező végeselemek (T3D2) lettek alkalmazva, míg a betonfajtákhoz téglaszerü, 8 csomópontos tömör végeselemek (C3D8R), 8 mm-es diszkretizálással. A beton és az erősítés között tökéletes tapadás (Perfect Bond) volt elképzelve. A betonfajták viselkedése CDM (Concrete Damage Plasticity) alapján történt, az erősítésekhez pedig olyan anyagviselkedési mód lett rendelve, mely szintén megengedte a nem-lineáris válaszokat (Material Pasticity).

Öt összehasonlító vizsgálat lett elvégezve a homlokzati lemezek esetében és három a lámpaoszlop modellre, a betontípusok anyagának a függvényében. Mindegyik esetnél egy olyan nem-lineáris Riks-féle eljárás lett alkalmazva, mely fokozatosan növeli a terhelést addig, amíg a szerkezeti elemek ki nem merítik a teherbírásukat, vagy el nem vesztik a stabilitásukat.

\section{Eredmények}

\subsection{Homlokzati lemezek}

A numerikus szimulációkból származó eredményeket grafikus formában ábrázoltuk mind a két szerkezeti elem esetében. A homlokzati lemezek esetében megfigyelhető, hogy az alacsonyabb nyomószilárdságú osztályoknál az első képlékeny alakváltozások kisebb erőknél jelennek meg, de a teherbírási tartalékok hasonlóak a maga- 
sabb osztályú betonból modellezett lemezekéhez (4. ábra).

Az 5. ábrán a nyomásra, illetve a 6. ábrán a feszítésre jellemző maradandó alak-változások kialakulását lehet követni.

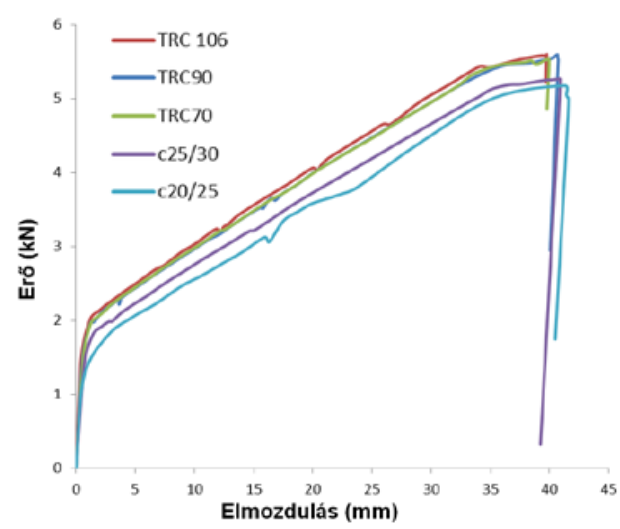

4. ábra. Erö-út diagramok a homlokzati lemezek esetében (az anyag-modellek jelölései a görbék sorrendjét követik).

Az alacsonyabb osztályú betonból készült modellek gazdasági megfontolásokból voltak számításba véve. Bár, elvileg lehetséges lenne ilyen alacsonyabb osztályú betonokat használni a TRC lemezeknél, a müszaki követelmények miatt (melyek finom szemcsés adalékot írnak elö, a szálak közti hatékonyabb behatolás miatt) az alkalmazott beton recept magasabb osztályú anyagot kell eredményezzen a nyomószilárdság szempontjából [17].

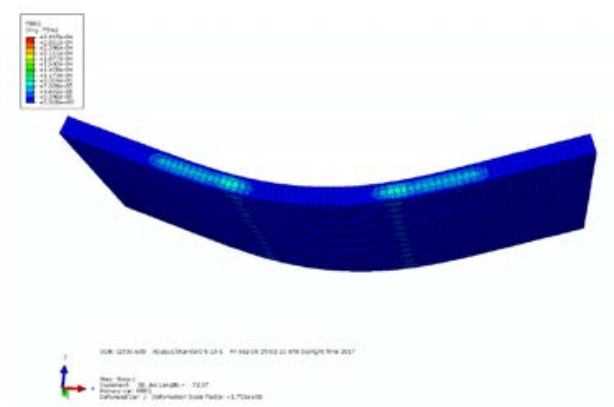

5. ábra. A nyomott részekre jellemző képlékeny alakváltozások kialakulása.

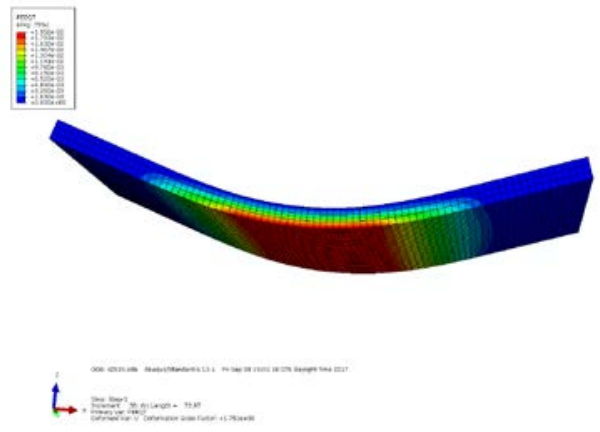

6. ábra. A feszülő részekre jellemző képlékeny alakváltozások kialakulása.

\subsection{Lámpaoszlopok}

A lámpaoszlopok viselkedésének a tanulmányozásánál, a modellezésénél merev befogás volt alkalmazva az alapnál, a terhelés pedig az oszlop magasságára kiterjedő egyenletesen eloszló volt (mint a már említett szélteher esetében).

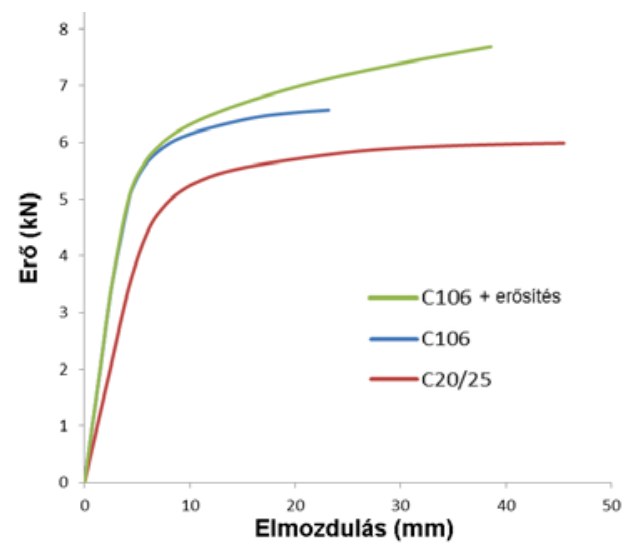

7. ábra. Erö-út diagramok a lámpaoszlopok esetében (az anyag-modellek jelölései a görbék sorrendjét követik).

A 7. ábrán látható, hogy az erősítés hatása aránylag csekély a TRC lámpaoszloppóknál. A textil erősítés az első képlékeny zónák kialakulásakor fejti ki igazán a hatását (az oszlop alján, a merev befogásnál), így a szerepe inkább abban nyilvánul meg, hogy teherbírási tartalékot biztosítson. 


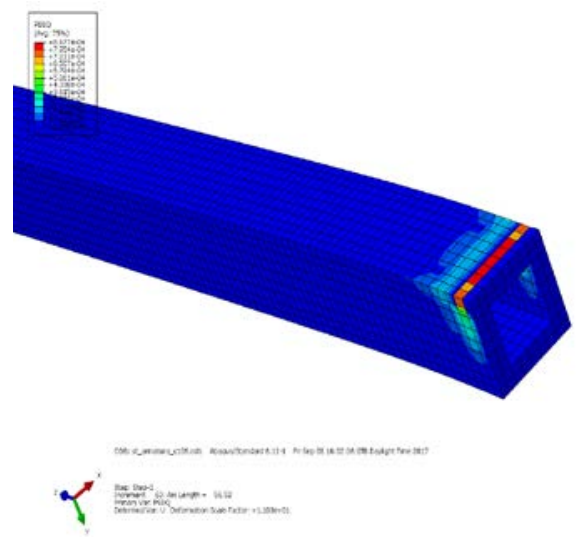

8. ábra. A nyomott részre jellemzö képlékeny alakváltozások a lámpaoszlop tövében.
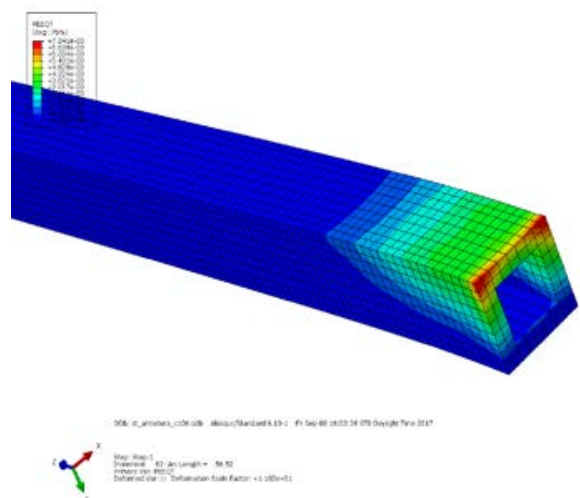

9. ábra. A feszülö részre jellemzö képlékeny alakváltozások a lámpaoszlop tövében.

\section{Következtetések}

A bemutatott számszerü vizsgálatok egyik célja az volt, hogy előzetes adatokkal szolgáljanak a későbbi gyakorlati kísérletek tervezéséhez (például a kísérletek számának az optimalizálásához, meg, hogy előre sugallják a vizsgálandó szerkezeti elemfajták viselkedését olyan életúti vizsgálatoknál, ahol minden nem-linearitási forrást figyelembe lehet venni.

Müszaki feltételek miatt nem lehetséges 4 mm-nél nagyobb szemcseméretü adalékanyag alkalmazása a textilbeton elemeknél, s ez nagyobb nyomószilárdsághoz vezet. Karcsú szerkezeti elemek gyártásához olyan erősítéseket kell alkalmazni, melyek korrózióállóak (így a hagyományos acél vasalás használata kizárt).

$\mathrm{Az}$ elvégzett számszerü vizsgálatok alapján a következőket lehet megállapítani:

- Alacsonyabb osztályú (kisebb nyomószilárdságú) textilbeton alkalmazása homlokzati lemezekben nem okoz lényeges merevségi és teherbírási eltéréseket;

- Úgy a homlokzati lemezek, mint a lámpaoszlopok esetében, a nagyobb nyomószilárdságú beton alkalmazása növeli az üzemelési teherbírást (a TRC homlokzati lemezeknél körülbelül 40\%-kal, a TRC lámpaoszlopoknál körülbelül 15\%-kal);

- A textil-erösítés szerepe a teherbírási tartalék olyszerü biztosítása, hogy a szerkezeti elem tönkremenetele előre észlelhető (jelzett) lehessen.

Fontos célkitűzés a fenntarthatósági feltételek teljesítési mértéke is (a megvalósításhoz szükséges anyagmennyiség, meg a bevitt energia csökkentése, az élettartam növelése mellett), illetve a gazdaságosság. A textilbeton alkalmazása nem feltétlenül olcsóbb, de előnyösebb, lehet.

\section{Szakirodalmi hivatkozások}

[1]Brameshuber, W. (ed.): Report 36: Textile Reinforced Concrete - State-of-the-Art Report of RILEM TC 201-TRC. Vol. 36. RILEM Publications S.A.R.L., Bagneux, Franciaország, 2006.

[2] Williams Portal, N.: Usability of Textile Reinforced Concrete: Structural Performance, Durability and Sustainability. PhD thesis, Chalmers University of Technology, Göteborg, Svédország, 2015.

[3] Contamine, R., Si Larbi, A., Hamelin, P.: Identifying the contributing mechanisms of textile reinforced concrete (TRC) in the case of shear repairing damaged and reinforced concrete beams. Engineering Structures, vol. 46, nr. 1/2013, Elsevier (DOI: 10.1016/j. engstruct.2012.07.024), 2013, 447-458. oldal.

[4]Brückner, A., Ortlepp, R., Curbach, M.: Anchoring of shear strengthening for T-beams 
made of textile reinforced concrete (TRC). Materials and Structures, vol. 41, no. 2/2008, Springer (DOI: 10.1617/s11527-007-9254-9), 2008, 407-418. oldal.

[5] Papanicolaou, C. G., Triantafillou, Th. C., Papathanasiou M., Karlos, K.: Textile reinforced mortar (TRM) versus FRP as strengthening material of URM walls: out-ofplane cyclic loading. Materials and Structures, vol. 41, no. 1/2008, Springer (DOI: 10.1617/s11527-007-9226-0), 2008, 143-157. oldal.

[6]Bernat-Maso, E., Gil, L., Roca, P.: Numerical analysis of the load-bearing capacity of brick masonry walls strengthened with textile reinforced mortar and subjected to eccentric compressive loading. Engineering Structures, vol. 91, Elsevier (DOI: 10.1016/j.engstruct. 2015.02.032), 2015, 96-111. oldal.

[7] Verbruggen, S., Aggelis, D. G., Tysmans, T., Wastiels, J.: Bending of beams externally reinforced with TRC and CFRP monitored by $D I C$ and $A E$. Composite Structures, vol. 112, Elsevier (DOI: 10.1016/j.compstruct.2014. 02.006), 2014, 113-121. oldal.

[8]Hegger, J., Kulas, Ch., Horstmann, M.: Spatial textile reinforcement structures for ventilated and sandwich façade elements. Advances in Structural Engineering, vol. 15, Issue 4, SAGE Publications (DOI: 10.1260/ 1369-4332.15.4.665), 2012, 665-675. oldal.

[9] Schneider, H. N., Schätzke, Ch., Feger, Ch., Horstmann, M., Pak, D.: Modulare Bausysteme aus Textilbeton- sandwichelementen, Textilbeton - Theorie und Praxis: Tagungsband zum 4. Kolloquium zu textilbewehrten Tragwerken (CTRS4) und zur 1. Anwendertagung, T. U. Dresden, Németország, 2009, 565-576. oldal.

[10] Chira, A., Kumar, A., Vlach, T., Laiblová, L., Škapin, A. S., Hájek, P.: Property improvements of alkali resistant glass fibres/epoxy composite with nanosilica for tex- tile reinforced concrete applications. Materials \& Design, vol. 89, 2016, Elsevier (DOI: 10.1016/j.matdes.2015.09.122), 2016, 146155. oldal.

[11] Chira, A., Kumar, A., Vlach, T., Laiblová, L., Hajek, P.: (2016). Textile-reinforced concrete facade panels with rigid foam core prisms. Journal of Sandwich Structures \& Materials, vol. 18, Issue 2/2016, SAGE Publications (DOI: 10.1177/1099636215613 488), 2016, 200-214. oldal.

[12] Gopinath, S, Kumar, V. R., Sheth, H., Murthy, A. R., Iyer, N. R.: Pre-fabricated sandwich panels using cold-formed steel and textile reinforced concrete. Construction and Building Materials, vol. 64, Elsevier (DOI: 10.1016/j.conbuildmat.2014.04.068), 2014, 54-59. oldal.

[13] Shams, A., Hegger, J., Horstmann, M.: An analytical model for sandwich panels made of textile-reinforced concrete. Construction and Building Materials, vol. 64, Elsevier (DOI: 10.1016/j.conbuildmat.2014.04.025), 2014, 451-459. oldal.

[14] Dey, V., Zani, G., Colombo, M., Di Prisco, M., Mobasher, B.: Flexural impact response of textile-reinforced aerated concrete sandwich panels. Materials \& Design, vol. 86, 12/2015, Elsevier (DOI: 10.1016/j. matdes.2015.07.004), 187-197. oldal.

[15] Hegger, J., Voss, S.: Investigations on the bearing behaviour and application potential of textile reinforced concrete. Engineering Structures, Vol. 30, no. 7/2008, Elsevier (DOI: $\quad$ 10.1016/j.engstruct.2008.01.006), 2008, 2050-2056. oldal.

[16] ABAQUS, Finite element software, Hibbitt, Karlsson \& Sorensen Inc., USA.

[17] Kausay, T.: Beton. A betonszabvány néhány fejezetének értelmezése, Mérnöki Kamara Nonprofit Kft, Budapest, Magyarország, 2013. 